\title{
JURIDICAL ANALYSIS OF SANCTIONS TRESPASSER AGAINST NARCOTIC'S VICTIM BASED ON UTILITARIANISM JUSTICE VALUES
}

\author{
Andri Winjaya Laksana \\ Lecturer Faculty of Law UNISSULA \\ andriwinjaya@gmail.com \\ Arpangi \\ Lecturer Faculty of Law UNISSULA \\ arpangi@unissula.ac.id
}

\begin{abstract}
Utilirarisme have a basic philosophical principle or very firm stance that any fair punishment for wrongdoers must look further consequences. In law enforcement against narcotic crime, repressive efforts have been made ranging from arrest until the legal process in court. However, until now the number of drug abusers tend to increase. The public and law enforcement officers themselves, drug abusers are considered criminals who should be punished. Helpful punishment is punishment that brings meaning and positive value for the subject of the condemned, the general public and the potential criminals in society. Helpful punishment for violators of law that is deterring offenders, with the aim to create a future inmate subject better. By implementing a sentence of imprisonment to the victims of abusers of narcotics is an action that is not quite right, because a victim abusers of narcotics can be categorized as human physical and spiritual health problems, a sick person handling must be healed, and not send him to prison to collect the perpetrators of acts criminal
\end{abstract}

Keywords: Conviction, Victims of narcotics abuse, Utilitarianism Justice.

\section{A. Introduction}

The development of narcotic crime as transnational crime and organized crime has made Indonesia as a country that backs possess drugs emergency status. Narcotics initially only used as a tool for religious rituals, and in addition, it is also used for treatment. The first type of drug-use in the beginning is usually referred to as the opium or opium or opium. ${ }^{1}$

1 Kusno Adi, Diversi Sebagai Upaya Alternatif Penanggulangan Tindak Pidana Narkotika Oleh
Laws governing narcotics and illegal drugs, namely Act No. 5 of 1997 on Psychotropic Substances and the Act No. 22 Of 1997 on Narcotics which has been converted into Act No. 35 of 2009 by means of penal (criminal law $)^{2}$ to cope with the dangers of drug abuse.

Penal is the application of criminal law, the criminal law is basically

Anak, Cetakan Pertama, UMM Press, Malang, 2009 , p. 3.

2 Barda Nawawi Arief, Kapita Selekta Hukum Pidana, Cetakan Ketiga, Citra Aditya Bakti, Bandung, 2013, p. 94. 
set and determine what conduct is prohibited and is included in a criminal act, and determine the criminal penalties that may be imposed or the person who did.

In Act No. 35 of 2009 as a penal to combat narcotic crime, narcotics offenses set on problems, which are more fully described in Chapter XV of the Criminal Provisions consisting of 38 in the same chapter, such as the Criminal Code. In Act No. 35 of 2009, the narcotics are divided into class I, class II, and class III. Group I considered more dangerous than class II and class III. Similarly, the class II are seen as more dangerous than class III, so that the criminal threat stratified according to the class.

Criminal penalty in Act No. 35 of 2009 was also stratified according to our works and the total weight of each type. In addition, the provisions of Article 113 paragraph (2), Article 114 paragraph (2), Article 115 paragraph (2), Article 116 paragraph (2), Article 118 paragraph (2), Article 119 paragraph (2), Article 121 paragraph (2) and Article 38 (2) of Act No. 35 of 2009 listed the imposition of the death penalty in addition to imprisonment and criminal fines. The problem is how the mechanism defined, and whether to pen-dropping death penalty must be accompanied by criminal penalties clicking normative juridical remember these things can not be justified. ${ }^{3}$

In the imposition of criminal sanctions, the doers have the role, position and different sanctions, both

3 Andi Hamzah dan Boedi Dwiyani Sri Marsita Goenanti, Kejahatan Narkotika \& Psikotropika, Cetakan Pertama, Universitas Trisakti, Jakarta, 2011, p. 33 and 34. on a per rule of law that govern it, and based on the role and impact of deeds.

It is necessary to note also, there is the classification of the doers that must be observed by the law enforcement agencies in the implementation of Act No. 35 of 2009. Classification of the doers can be seen from several aspects as in Act No. 35 of 2009 and the provisions of law relating to narcotic crime. Penal provisions against the doers in Act No. 35 of 2009 under Article 111 to Article 147.

Importance to determine the classification of the offender narcotics, show that every action and position the doers have different sanctions. It is not in spite of the impact that may result from the criminal act of narcotics. State can not arbitrarily determine which acts as criminal offenses and sanctions should be imposed on the offender, and must be grounded principle of equality before the law as a reflection of justice.

Associated with criminals, one thing that is the problem in the Act No. 35 of 2009 is the uncertainty on the definition and status among addicts, abusers and victims of abuse of narcotics Act No. 35 Of 2009 on Narcotics also contains Article 54 which governs rehabilitation. Article 54, which reads "drug addicts and victims of abuse of narcotics are required to undergo medical rehabilitation and social rehabilitation. ${ }^{4}$ Medical rehabilitation is a process of integrated treatment activities to free addicts from drug addiction. Medical Reahabilitasi drug addicts can be done in a hospital designated by the health minister that

4 See Act No. 35 of 2009 on Narcotics 
the hospital organized both by government and by society.

In addition to medication or treatment through medical rehabilitation, the healing process of drug addicts can be held by the public through religious and traditional approaches. While social rehabilitation is a process of recovery activities in an integrated manner, both physically, mentally and socially so that former drug addicts can be immediately reperform a social function in the conduct of public life. What is meant here is former drug addicts who have recovered from drug dependence physically and psychologically. ${ }^{5}$

Their juridical problems in Act No. 35 of 2009 will mengambat efforts of the law enforcement agencies in the prevention and eradication of narcotics, so that the juridical issues need to be formulated in policy formulation narcotic crime criminal sanctions in the future, which can meet the objectives of the law, namely the rule of law, expediency and fairness.

The scope of criminal law policy actually covers one wide, which includes an evaluation of the substance of criminal law (ius constitutum) for the renewal of the substance of criminal law in the future (ius constituendum), by means of the application of criminal law through components of the criminal justice system, tahui capabilities to whether the substance of the criminal

5 Andri Winjaya Laksana, Pelaksanaan Pemeriksaan Terhadap Pelaku Penyalahguna Narkotika Dengan Sistem Rehabilitasi di Badan Nasional Narkotika Propinsi Jawa Tengah, Jurnal Pembaharuan Hukum Volume III No. 2 May to August 2016, p.253-263. law has fulfilled sense of justice or otherwise. $^{6}$

Community justice sometimes difficult to realize in this country Indonesian law. As in the case of narcotic crime, as it is known that the form of criminal sanctions can be imposed for offenses proven in court form of imprisonment, fines and rehabilitation. However, for addicts or drug abusers improper victim when sentenced to prison, and it was contrary to Law Number 35 Of 2009 jo. SEMA No. 4 of 2010. However, there are still judges who shortly imprisonment drop to addicts or drug abusers victim, causing contradictory to the laws and practices on the ground. Dropping imprisonment in addicts and drug abusers victim has violated the rules of Act No. 35 Of 2009 jo. SEMA No. 4 of 2010 , in which one set addicts or drug abusers must be rehabilitated. It is not easy to declare the perpetrators are as addicts, victims of drug abuse or a dealer.

Of course, any imposition of criminal sanctions should be of benefit to the offender in private, that can correct the error of the perpetrators and offenders not to repeat his actions again, and to society in general is security and order obtained by the prevention and eradication narcotics.

An examination of the offender improvement, measures of effectiveness lies in the aspects of specific prevention (special prevention) of the criminal. So, its size lies in the criminal matter how far away (in prison) have an influence

6 Dahlan, Problematika Keadilan Dalam Penerapan Pidana Terhadap Penyalahguna Narkotika, Cetakan Pertama, Deepublish, Yogyakarta, 2017, p. 2 and 3. 
on the offender or convicted. There are two aspects of criminal influence against the convict, the early prevention aspects (deferent aspect) and aspects of improvement (reformative aspect). ${ }^{7}$ A good law would be run if there is a substance that can be useful as a means of justice and law enforcement officials who supported consistently follow these substances and consistently uphold human rights. ${ }^{8}$

Regulations written in the law is a fixed price that can no longer be contested by anyone, including law enforcement. Appropriate criminal sanctions for the perpetrators of the crime of narcotics, will be able to provide a deterrent effect and would facilitate the government's efforts in the prevention and eradication of narcotics.

\section{B. Discussion}

Act No. 35 of 2009 is a public law, as in Act No. 35 of 2009 set the general interests of society as a watchdog of government and involve the enactment of the Act. Act No. 35 of 2009, including the criminal law, the law that regulates all provisions concerning narcotics and there are criminal sanctions for the violation of the Act, so that in an effort to estab-berantasan narcotic crime, Act No. 352009 should be enforced regardless of office or social status of the offender.

Basically, the law of criminal influence or intervene in people's lives through three stages. Muladi mention of

7 Dawud Budi Sutrisno, Pengaturan \& Penerapan Hukum Pidana Narkoba, Cetakan Pertama, Yuma Pustaka, Surakarta, 2012, p. 54.

8 Dahlan, op.cit., p. 4. three (3) stages in criminal law enforcement policy, namely: ${ }^{9}$

1. Formulation stage, the stage of rule of law in abstracto by the lawmaking body. This stage can also be called the stage of legislative policy;

2. Application stage, the stage of the application of criminal law by law enforcement officers, from police to courts. This second phase can also be called the stage of judicial policy;

3. The execution phase, the implementation phase of the criminal law in concrete by the criminal executive officers. This stage can also be called executive or administrative policy stage.

Criminal law policy is an attempt to realize criminal laws appropriate to the circumstances and the situation at a time and for the foreseeable future. ${ }^{10}$ In effect, the policy for the regulation of criminal law for the better, along with the times, criminal law policy is part of efforts in the prevention of crime. Thus, the criminal law policy is part of a crime prevention policy (criminal politics).

Policy formulation of criminal law is the most strategic phase of efforts to combat crime through "penal policy". Therefore, the error / weakness of policy formulation can be seen as a strategic error and therefore may inhibit

9 Muladi, Kapita Selekta Sistem Peradilan Pidana, Badan Penerbit Universitas Diponegoro, Semarang, 1995, p. 13.

10 Al Wisnubroto, Kebijakan Hukum Pidana Dalam Penanggulangan Penyalahguna-an Komputer, Universitas Atmajaya, Yogyakarta, 1999, p. 11. 
or at least affect the effectiveness of crime prevention to criminal law. ${ }^{11}$

Thus, it can be seen very important role of law to safeguard the interests of the community of action the parties that may be detrimental to the people's interest, with powers that meforcing, then the law can be enforced and the presence of criminal sanctions be expected to provide a deterrent effect for offenders criminal act.

Laws in the form of laws made by the legislature should be implemented or executed as well as possible by the community, and if there is a violation, then law enforcement will handle the offense in accordance with the provisions of the law per the invitation. The principle of the enactment of the law is to create a justice that can be applied in the community, in terms of the application of the principles of justice accomplishment of the theory of justice in the law enforcement community, among others, the theory of justice Benthamism initiated by Jeremy Bentham, which is one school of philosophy that made important contributions in the application of punishment to humans.

Utilirarisme have a basic philosophical principle or very firm stance that any fair punishment for wrongdoers must look further consequences. This theory is actually a form of applied are limited of the basic principles of utilitarianism ethics which states that an action is morally justified only good consequences for many people as possible

11 Barda Nawawi Arief, Capita Selecta ..., op.cit., p. 93 and 94.
Bentham theory of punishment based on the principle of expediency (Principle of Utility). In his phenomenal (published in 1960), entitled Introduction to the Principles of Morals and Legislation, Bentham outline the direction and vision of the law from the perspective of psychological depth of the principle of utilitarianism. Bentham wrote: "Nature has placed mankind under the rule, namely displeasure and pleasure. What should we do and what we will do everything addressed and defined in the framework of both. The standard is good and bad, as well as the chain of cause and effect, is also closely related to two matters. Both guide us in everything we do, in all we say and think. All attempts to do is to refuse ketaklukan us against two powers, it will only prove and affirm the truth of it ". Using the term of utility or expediency, Bentham asserts a factual truth that everyone tends to turn a profit, benefit, advantage, pleasure, kindness and happiness for himself. This means that every person in the act tends to avoid themselves from situations misfortune, pain, evil, unhappiness, and unhappiness that disturb the tranquility itself. From the writings of Bentham above, we can conclude that the happiness of each individual in life worth protecting, maintained and preserved. ${ }^{12}$

From this comes the Greatest Happiness Theory of Bentham which confirms that the ultimate goal of everyone in this life that is happiness. People might not want to be happy living the reality of pilgrimage existence

12 Frederikus Fios, Keadilan Hukum Jeremy Bentham Dan Relevansinya Bagi Praktik Hukum Kontemporer, Jurnal HUMANIORA Vol.3 No.1 April 2012: 299-309. 
in this life. Happiness is the highest goal of every human person. In fact, it must be said happiness is a possibility ultima every human being on this planet.

Happiness and pleasure are diorbitkan Bentham not only refer to the consequences of human actions subjectively (personally) but also in the form of action that was decided by the government authorities or institutional policy that has the authority to regulate the law in the country. Institutions in this context of course is legally competent institutions provide sentenced to a prisoner subject (court). Seen here that the scope or very broad constellation Benthamism thought well it covers the individual dimension and the social dimension. And therefore, Bentham set it as a fundamental principle of the laws of morality. Departing from this we come to the important question of how the utility theory is applied to the penalty for inmate personal subject.

With prevention (preventive), Bentham indicated will appear three (3) the effects of which are: first, the sentences received by offenders result that he lost the ability to later repeat the same crime. If the prisoner locked up in prison for life, hand cut or even executed by the verdict of the formal system.

Second, the effect of punishment can also be changes or updates to the inmate. This presupposes punishment and refurbish affect any tendencies or habits that are not good in themselves the subject of a prisoner, so that he does not want to commit crimes in the future. Here the mentality of the reformed so that when freed later, he no longer wanted or want to commit an unlawful act. This presupposes the inmate has undergone transformation after undergoing stages of the legal process as long as he was in the prison bars. Thirdly, the deterrent effect and deterrence (deterrence). Punishment must be capable of deterring the subject of the condemned and also ward off evil from other potential criminals in society.

This punishment makes people who have been released from prison kapok (deterrent) to run riot again at once to give a message to other members of society to no longer commit crimes in reality a new kind of society. Wesley Cragg judge that the deterrent function of punishment effects can be understood as a form of social control. While Philip Benn said the intention behind deterrence is threatening other people for the future is no longer commit crimes. ${ }^{13}$

In addition to the primary purpose of punishment above, Bentham also outlined a secondary purpose of punishment are closely associated with the probability or potential violation of law in the future. In this context Bentham talk about legal satisfaction. Satisfaction through punishment will be achieved within two (2) forms as follows: first, compensation material and a second form of impingement or expression of resentment. Although the first type is difficult to apply in all cases of the law, but according to Bentham, punishment material compensation brought a lot of pleasure for people.

These are the main lines of thought Bentham on the principle of usefulness (utility) behind the penalty applied to a condemned man. Bentham 
thought about this, JS Mill once wrote that Bentham has created an almost perfect theory of justification of legal punishment that can be used in the framework of criminal law enforcement for criminal prosecution narcotic crime.

In order to achieve the objectives that the criminal law policy through legislation, in this case is Act No. 35 of 2009 is putting drug users as victims in need of rehabilitation both medical and social rehabilitation and not as criminals are sentenced to imprisonment and put into prisons.

Medical rehabilitation provided to victims of Narcotics abuse is done by giving certain drugs to reduce dependence on narcotics. Surely this administration adapted to the needs or level of pain experienced due to sakau. Medical rehabilitation is a field specialist in medical science that deals with the handling of the overall (comprehensive management) of patients with impaired function / injury (impairment), (musculos keletal), the composition of the neuromuscular (system), as well as interruptions of mental, social and workmanship accompanying the disability. To pelaksananaan medical rehabilitation arranged in PERMENKES No. 2415 / Menkes / Per / XII / 2011 on medical rehabilitation addicts, abusers Victims of Abuse of Narcotics and PERMENKES No. 502015 on technical guidelines Mandatory Implementation Report and medical rehabilitation for addicts, abusers and victims of narcotics abusers. ${ }^{14}$

14 Dina Novitasari, Rehabilitasi Terhadap Terhadap Anak Korban Penyalahgunaan Narkoba, Jurnal Hukum Khaira Ummah Vol. 12. No. December 4th 2017, p.917-926
While social rehabilitation is the process of recovery for victims of drug abuse in order to be reintegrated into society, especially among children themselves. Social rehabilitation set in Permensos No. 26 of 2012 on Standards of Social Rehabilitation of Drug Abusers. To determine the effectiveness of the social rehabilitation of drug addicts minors, it can be seen from several indicators including: understanding of the program, targeting accuracy, timeliness, achievement of targets, the achievement of goals and real change. If these indicators are met and implemented in practice, it can be said to be effective and vice versa if it did not happen then it is not very effective rehabilitation. The purpose of social rehabilitation of drug addicts is to be able to re-implement the social function of the dimasyarakat.Terkait with social rehabilitation of drug addicts minors then the goal is that the child can return to his world as a child and is no longer using drugs.

In law enforcement against narcotic crime, repressive efforts have been made ranging from arrest until the legal process in court. However, until now the number of drug abusers tend to increase. The public and law enforcement officers themselves, drug abusers are considered criminals who should be punished. This situation resulted in the emergence of other problems, such as the burden of correctional institutions (prisons) to over-capacity, the penitentiary became a safe haven for drug abusers and the emergence of other crimes, in addition to drug trafficking are also rife in prisons 
even several times in the pro-duction drugs in prisons. ${ }^{15}$

Approaches to reduce the number of drug abusers solution for this can be seen from the two (2) different viewpoints, namely: ${ }^{16}$

a. The first priority standpoint of law enforcement efforts by the imposition of criminal sanctions for drug abusers to obtain a deterrent effect;

b. The second viewpoint, using rehabilitation efforts to re-urangi black market which is assumed to affect the decline in demand (demand) for drugs.

Basically, sanctioned in Act No. 35 of 2009 embraced a double track system, namely in the form of criminal sanctions and the sanctions measures. Rehabilitation is one form of sanctions measures. In Article 103 of Act No. 35 of 2009 confirmed that the judge can decide or define drug addicts to undergo treatment and / or care. The period of treatment and / or care of a sentence is calculated as period. This is consistent with the one goal of the establishment of Act No. 35 of 2009, which guarantees the setting efforts of medical and social rehabilitation for drug addicts.

However, judges tend to impose a sanction of imprisonment in addicts. As a result, drug addicts languishing in prisons-more community without being given the opportunity rehabilitated, so that rehabilitation has not run optimally. Currently the number of prisoners in Indonesia reached 23779 people who are drug abusers who undergo

15 Dahlan.Op.Cit, p.58

16 Ibid., p. 78. imprisonment in a correctional institution. ${ }^{17}$

By looking at the circumstances of this kind, it will culminate in the completion of the no drug issues, because this is tantamount to move addicts into prison wall with no effort be healed, even plunged into illicit trafficking. Basically, drug addicts have addiction properties with a high relapse rate, so it can not recover by itself. They need to be helped to cure. Therefore, there should be a new paradigm in the treatment of drug addicts.

In dealing with drug addicts, law enforcement officers must be oriented to the sanctions, the form of rehabilitation for the sake of menyelamat-kan their future. In order to enable the role of judges in deciding or establish rehabilitation needs support from other law enforcement officials. Of course this should be based on the understanding and agreement that drug abuse is a serious problem of the nation and the enemy of the nation. Government and law enforcement officials shall unite their vision and mini to combat drug abuse in order to realize the noble ideals of the nation make the generation of a healthy nation.

Understanding and agreement of the government and law enforcement officials have realized through the Joint Regulation of the Chief Justice, the Minister of Law and Human Rights, the Minister of Health, Minister of Social Affairs, the Attorney General, the Chief of Police, Head of the National Narcotics Agency, No. 01 / NT / MA / I11 / 2014, No. 03 of 2014, No. 11 of 2014, No. 03 of 2014, No. PER-005 / A / JA /

17 Ibid. 
03/2014, No. 1 of 2014, No. joint regulation / 01/111/2014 / BNN on Narcotic addict Treatment and Abuse of Narcotics Into The Rehabilitation Institute. Thus, drug addicts no longer lead to the sanction of imprisonment, but empties into rehab, as agreed in the form of sanctions for addict rehabilitation. ${ }^{18}$

Victim trespasser required more attention, because to do rehabilitation should receive the full attention of all parties, but in the treatment and care efforts are made not optimal and integration improvement. Stated into consideration for the Supreme Court and other law enforcement agencies to make a joint regulation (Joint Regulation) No. 012014 About the Narcotic Addict Treatment Narcotic abusers and victims in the Rehabilitation Institute. Meaning the joint regulation No. 012014 On the optimal coordination and cooperation in solving problems of narcotics and can reduce the number of offenders and victims abusers abusers through the rehabilitation program, then in the joint regulation No. 01 of 2014 contained a description of the Integrated Assessment Team. ${ }^{19}$

As mentioned that Act No. 35 of 2009 embraced a double track system in the formulation of sanctions against the crime of injecting drugs, although still freedom for judges in sentencing in the decision in handling cases drug addicts (based on the belief the judge) in the case of sanctions measures.

18 Ibid., P. 79.

19 Andri Winjaya Lieu, Punishment Law Review Performers abusers Against Narcotics With Rehabilitation Systems, Journal of Law Reform Volume II \# January 1 of April 2015. Pg 74-85
Double track system in the formulation of sanctions against drug abuse is a criminal law policy in the formulation of provisions governing the sanctions given to the perpetrators of the abuse of narcotics, namely in the form of criminal sanctions and sanctions action because the actors in drug abuse have a slightly different position to the perpetrators of criminal acts another of his. On the one hand, he is a criminal who should be in-laws, but on the other hand is a victim of a criminal act he was doing it alone, so we need some form of rehabilitation measures. ${ }^{20}$

Determination of sanctions against drug addicts, whether to apply penal sanctions or measures, determination in the hands of judges. Because based on the provisions of Act No. 35 of 2009, mem-given authority for the judge to determine the will convict prison or rehabilitation measures against the drug addicts. To determine whether in handling cases drug addicts, the judge will apply the provisions of Article 127 of Act No. 35 of 2009 (regulating the criminal sanctions) or apply the provisions of Article 103 of Act No. 35 of 2009 (regulating sanctions rehabilitation measures) is in the end boils down to the belief judge whether the offender narcotics abuse the right to be regarded as addicts should be rehabilitated or more correct to say as a criminal abuse of drugs should be sentenced to imprisonment is based on the description of the laboratory stating that the perpetrators are addicted to narcotics, thus requiring the process care and / or treatment performed through the rehabilitation facilities and

20 Dahlan, Op.Cit.hlm 153 
the course is based on the provisions of law.

Key meaning in the term or vocabulary Bentham utility that is expediency. In the subject punish the prisoner, law enforcement agencies or any competent authority should certainly consider the benefits of penalties for offenders subject. Is it positive benefit punishment for offenders subject to the future, here to note the mechanism of execution of the sentence to fit the purpose of punishment itself. If the penalty was not useful, the punishment is not fair. Punishment would be a formalistic practices that use values lost relevance. Helpful punishment is punishment that brings meaning and positive value for the subject of the condemned, the general public and the potential criminals in society. Helpful punishment for violators of law that is deterring offenders, with the aim to create a future inmate subject better. Any form of punishment that does not guarantee a better future for the subject of the condemned, worthy even explicitly rejected. Here we talk about the inmate's own happiness for the subject. If the right of every human being that wants to live happily in this life is important, then the punishment is necessary that ensure the inmate's life subject in a state of happy future. Penalties run by the subject of the prisoner, to make his life less happy.

\section{Conclusion}

Utilirarisme have a basic philosophical principle or very firm stance that any fair punishment for wrongdoers must look further consequences. This theory is actually a form of applied are limited of the basic principles of utilitarianism ethics which states that an action is morally justified only good consequences for as many people as Bentham theory of punishment based on the principle of expediency (Principle of Utility). In his book entitled Introduction to the Principles of Morals and Legislation, Bentham outline the direction and vision of the law from the perspective of psychological depth of the principle of utilitarianism. Helpful punishment is punishment that brings meaning and positive value for the subject of the condemned, the general public and the potential criminals in society. Helpful punishment for violators of law that is deterring offenders, with the aim to create a future inmate subject better. By implementing a sentence of imprisonment to the victims of abusers of narcotics is an action that is not quite right, because a victim abusers of narcotics can be categorized as human physical and spiritual health problems, a sick person handling must be healed, and not send him to prison to collect the perpetrators of acts criminal. 


\section{BIBLIOGRAPHY}

\section{Books}

Abdul Wahid dan Mohammad Labib, 2005, Kejahatan Mayantara (Cybercrime), Cetakan Kesatu, Refika Aditama, Bandung;

Al Wisnubroto, 1999, Kebijakan Hukum Pidana Dalam Penanggulangan Penyalahgunaan Komputer, Universitas Atmajaya, Yogyakarta;

Andi Hamzah dan Boedi Dwiyani Sri Marsita Goenanti, 2011, Kejahatan Narkotika \& Psikotropika, Cetakan Pertama, Universitas Trisakti, Jakarta;

Barda Nawawi Arief, 2013, Kapita Selekta Hukum Pidana, Cetakan Ketiga, Citra Aditya Bakti, Bandung;

Dahlan, 2017, Problematika Keadilan Dalam Penerapan Pidana Terhadap Penyalahguna Narkotika, Cetakan Pertama, Deepublish, Yogyakarta;

Dawud Budi Sutrisno, 2012, Pengaturan \& Penerapan Hukum Pidana Narkoba, Cetakan Pertama, Yuma Pustaka, Surakarta;

Kusno Adi, 2009, Diversi Sebagai Upaya Alternatif Penanggulangan Tindak Pidana Narkotika Oleh Anak, Cetakan Pertama, UMM Press, Malang;

Muladi, 1995, Kapita Selekta Sistem Peradilan Pidana, Badan Penerbit Universitas Diponegoro, Semarang.

\section{Journal}

Andri Winjaya Laksana, Tinjauan Hukum Pemidanaan Terhadap Pelaku Penyalahguna Narkotika Dengan Sistem Rehabilitasi, Jurnal Pembaharuan Hukum Volume II No. 1 January-April 2015.

Pelaksanaan Pemeriksaan Terhadap Pelaku Penyalahguna Narkotika Dengan Sistem Rehabilitasi di Badan Nasional Narkotika Propinsi Jawa Tengah, Jurnal Pembaharuan Hukum Volume III No. 2 May - August 2016

Dina Novitasari, Rehabilitasi Terhadap Terhadap Anak Korban Penyalahgunaan Narkoba, Jurnal Hukum Khaira Ummah Vol. 12. No. 4 December 2017;

Frederikus Fios, Keadilan Hukum Jeremy Bentham Dan Relevansinya Bagi Praktik Hukum Kontemporer, Jurnal HUMANIORA Vol.3 No.1 April 2012. 